\title{
Arteriosclerosis in Parkinsonism
}

\author{
M. J. EADIE AND J. M. SUTHERLAND \\ From the Neurological and Medical Professorial Unit, Brisbane Hospital, Australia
}

Some textbooks on general and neurological medicine give the impression that cerebral arteriosclerosis is an important cause of Parkinsonism (e.g., Alpers, 1945; Yater, 1949; Purves-Stewart and Worster-Drought, 1952; Wilson, 1955; Cecil and Loeb, 1959; Grinker, Bucy, and Sahs, 1959; Merritt, 1959; Baker, 1962; Brain, 1962). Whether or not this is so, it is often very difficult to distinguish clinically between arteriosclerotic and other aetiological types of Parkinsonism in the individual patient (Merritt, 1959). Experience of this difficulty has led to an examination of some aspects of the concept of arteriosclerotic Parkinsonism.

\section{HISTORICAL ASPECTS}

Although Parkinson described his 'shaking palsy' in 1817 , the entity did not attain general acceptance until Charcot (1877) differentiated Parkinsonian tremor from the ataxic tremor of multiple sclerosis. Subsequently isolated cases with atypical features were described (e.g., Buzzard, 1882; Mackintosh, 1903; Janischewsky, 1909), and, following the 19171926 epidemic of encephalitis lethargica, there appeared numerous instances of a new disorder fundamentally resembling paralysis agitans but differing from it in several respects (Hall, 1923). It became accepted that Parkinsonian features could have more than one aetiology, and the concept of a Parkinsonian syndrome, previously suggested by Brissaud (1895), became popular.

Brissaud (1895), Maillard (1907), Lewy, (1913), and Souques (1921) considered the possibility that cerebral arteriosclerosis might cause Parkinsonism, and Foerester (1909) described 'arteriosclerotic muscular rigidity', but the concept of 'arteriosclerotic Parkinsonism' largely stems from Critchley (1929), who described under this term a disorder characterized by Parkinsonian rigidity and various other features but not necessarily or even usually accompanied by tremor. Critchley (1929) was uncertain to what extent idiopathic and arteriosclerotic Parkinsonism were really separable. Subsequent authors (e.g., Alexander, 1942; Davison, 1942; Schneider and Williams, 1949; Doshay, 1954) widened the concept of arteriosclerotic Parkinsonism so that it came to resemble classical paralysis agitans rather more than had Critchley's (1929) original account.

Perhaps, partly in reaction to this blurring of aetiological identities, clinicians have more recently expressed misgivings concerning the role of arteriosclerosis in producing Parkinsonism (Schwab and England, 1958; Heyman, 1959; Howell, 1959; Merritt, 1959; Walton, 1961). Doshay (1960) now considers that 'the arteriosclerotic variety is undoubtedly part and parcel of the idiopathic'.

\section{PATHOLOGICAL ASPECTS}

The essential locus of pathology in Parkinsonism is uncertain. In paralysis agitans lesions have been described at many levels of the neuraxis, from cerebral cortex (Foix, 1921) to sympathetic ganglia (den Hartog Jager and Bethlem, 1960), but the most frequently mentioned and presumably significant ones lie in the substantia nigra (Brissaud, 1895; Tretiakoff, 1919; Foix, 1921; Hassler, 1938; Klaue, 1940; Greenfield and Bosanquet, 1953; Greenfield, 1955, 1958), the striatum (Lewy, 1913; Jakob, 1925; Hassler, Riechert, Mundinger, Umbach, and Ganglberger, 1960), or the pallidum (Lewy, 1913; Hunt, 1917, 1937; Foix and Nicolesco, 1925; DennyBrown, 1962).

Although Critchley (1929) did not consider pathological aspects of arteriosclerotic Parkinsonism at length, he suggested that haemorrhages, softenings and lacunae in the basal ganglia, midbrain, and elsewhere, with changes in blood vessel walls, were features which favoured this diagnosis. However, neuropathologists have not accepted this view unreservedly. Keschner and Sloane (1931) could not always distinguish between idiopathic and arteriosclerotic Parkinsonism. Denny-Brown (1954) queried Alexander's (1942) view that the characteristic 'état criblé' of the latter condition was due to arteriosclerosis. Wolf (1954) was disturbed at the poor correlation between the frequency of vascular lesions in the basal ganglia and the relative infrequency of Parkinsonism. Haymaker (1959) had 
TABLE I

COMPARISON OF CERTAIN CLINICAL FEATURES OF ARTERIOSCLEROTIC AND IDIOPATHIC PARKINSONISM

\begin{tabular}{|c|c|c|c|}
\hline . & Critchley (1929) & Doshay (1954) & Wilson (1955) \\
\hline $\begin{array}{l}\text { Age of onset in years } \\
\text { Arteriosclerotic Parkinsonism } \\
\text { Paralysis agitans } \\
\text { Mode of onset }\end{array}$ & $\begin{array}{l}\text { Over } 65 \text { (unless hypertensive) } \\
45 \text { to } 70\end{array}$ & $\begin{array}{l}55 \text { to } 70 \\
40 \text { to } 55\end{array}$ & $\begin{array}{l}\text { Old age } \\
50 \text { to } 60 \text { mainly }\end{array}$ \\
\hline $\begin{array}{l}\text { Arteriosclerotic Parkinsonism } \\
\text { Paralysis agitans } \\
\text { Course of arteriosclerotic Parkinsonism }\end{array}$ & $\begin{array}{l}\text { Insidious, but may be sudden } \\
\text { Insidious } \\
\text { More rapid than paralysis agitans, } \\
\text { but no time factors given }\end{array}$ & $\begin{array}{l}\text { Evanescent } \\
\text { Sudden }\end{array}$ & $\begin{array}{l}\text { At times quick } \\
\text { Gradual }\end{array}$ \\
\hline $\begin{array}{l}\text { Distribution of clinical manifestations } \\
\text { Arteriosclerotic Parkinsonism } \\
\text { Paralysis agitans }\end{array}$ & $\begin{array}{l}\text { Rarely unilateral } \\
\text { Commonly unilateral }\end{array}$ & $\begin{array}{l}\text { Hemi-involvement } \\
\text { Hemi-involvement }\end{array}$ & $\begin{array}{l}\text { Trunk and lower limb } \\
\text { mainly } \\
\text { May be partial, but be- } \\
\text { comes generalized }\end{array}$ \\
\hline $\left.\begin{array}{l}\text { Tremor } \\
\text { Rigidity }\end{array}\right\}$ In arteriosclerotic Parkinsonism & $\begin{array}{l}\text { Absent (except for occasional senile tremor) } \\
\text { Never cogwheel }\end{array}$ & $\begin{array}{l}\text { May be severe } \\
\text { May be cogwheel }\end{array}$ & Little or none \\
\hline
\end{tabular}

'seen no difference in the arterial walls in those with the Parkinsonian syndrome and in those without'. Denny-Brown (1962) attributed arteriosclerotic Parkinsonism to an exaggeration of the paravascular degeneration of the globus pallidus seen in paralysis agitans, together with an état criblé in the putamen. He indicated that clinically, and presumably pathologically, there were all degrees of transition between idiopathic and arteriosclerotic Parkinsonism.

Uncertainty about the site of the essential pathology of Parkinsonism increases the difficulty of evaluating pathologically the role of arteriosclerosis in the production of the condition.

\section{CLINICAL ASPECTS}

Consideration of several accounts of the condition shows sufficient discrepancy between descriptions of major clinical features for it to be scarcely possible to formulate a composite clinical picture of arteriosclerotic Parkinsonism as an entity distinct from other varieties of the syndrome. Table I sets out certain such features referred to by Critchley (1929), Doshay (1954), and Wilson (1955).

\section{THE PRESENT STUDY}

If arteriosclerosis is a significant cause of Parkinsonism, and Garland (1955) believed that $21 \%$ of his cases were of arteriosclerotic aetiology, it might be expected that there would be more clinically detectable arteriosclerosis in a series of cases of Parkinsonism than in a matched control series. This proposition has been investigated clinically.

MATERIal AND methods The Parkinsonian series consisted of 95 consecutive persons seen at the Brisbane Hospital with Parkinsonian rigidity and tremor. A control series of 96 persons with acute orthopaedic disorders, usually traumatic, without predisposing illness, was collected synchronously with the Parkinsonian series and matched with it for age and sex. Such a control series seemed to offer the best approximation to the general population that could be found among hospital patients. $c$ The age distributions of the two series are compared in Fig. 1; the sex ratio in the Parkinsonian series was $M: F:: 2 \cdot 24: 1$, and in the controls $M: F:: 2 \cdot 3: 1$.

It is very difficult to measure the degree of arteriosclerosis in a living person. The method used was to form an overall estimate from (1) the degree of palpable arteriosclerosis in the cervical carotid arteries, (2) the iv degree of palpable arteriosclerosis in the brachial arteriesp i $\omega$ (3) the degree of intolerance to exercise due to coronars in artery disease, (4) the degree of retinal arterial diseas $\mathcal{U}_{\mathrm{V}}$ (5) the elevation of the brachial blood pressure. A 1 to normality was graded $0,1,2$, or 3 units depending as to whether it was absent, mild, moderate, or severe. For the retinal arteries the units corresponded with the grades of

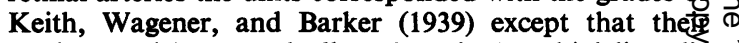
grades 3 and 4 were each allotted 3 units. Brachial diastolis. $\vec{\varphi}$ blood pressure was graded as follows:-Less than $90 \mathrm{~mm}$. Hg, 0; 90-105 mm. Hg, 1; 106-120 mm. Hg, 2; and $>120 \mathrm{~mm}$., $\mathrm{Hg}$ 3. The sum of the five individual measures of arterial disorder was taken as an estimate of the degree of arteriosclerosis in each person. It is realized that this

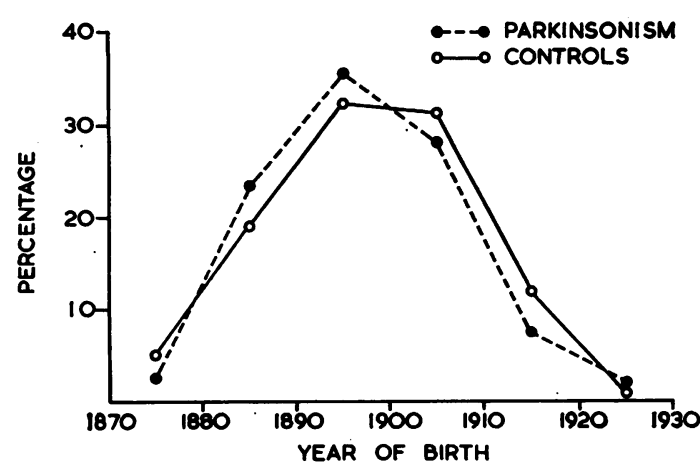

FIG. 1. Age distribution of Parkinsonian and control series. 
TABLE II

DISTURBANCES OF FUNCTION REGARDED AS COMPRISING PARKINSONISM

\begin{tabular}{lccccc} 
& & Rigidity & Tremor & Akinesia & Characteristic Facies and Appearances \\
\hline Critchley & $(1929)$ & + & O & + \\
Walshe & $(1955)$ & + & + & O & \\
Denny-Brown & $(1959)$ & + & Usual & \\
Hirano et al. & $(1961)$ & Usual & + & + & + \\
Aring & $(1962)$ & $(1962)$ & + & + & + \\
Brain & Herz and Meyers (1962) & + & +
\end{tabular}

is an imperfect measure of arterial disease, but it is on such data as these, and on the presence of presumed arteriosclerotic manifestations, that the clinician customarily assesses the extent of arteriosclerosis in a patient.

RESULTS For the 96 controls the mean estimate of arteriosclerosis was $2 \cdot 82 \pm$ S.D. $2 \cdot 25$ units per person. For the 95 cases of Parkinsonism the mean estimate was 2.93 士 S.D. 2.22 units per person. The difference batween the two means $(0 \cdot 11 \pm$ S.E. 0.41 units) is not statistically significant $(\mathrm{t}=0.27$, so $\mathrm{P}$ is $<0.75$ only, i.e., there are about three chances in four that there is no real difference between the two groups).

\section{DISCUSSION}

The present study has failed to demonstrate a significant association between Parkinsonism and arteriosclerosis estimated clinically. When its pathological basis and clinical diagnosis are both uncertain, one is perhaps entitled to question the validity of the concept of arteriosclerotic Parkinsonism. Confusion arises even from the word 'Parkinsonism', which is sometimes defined as a syndrome resembling Parkinson's disease without delineation of the necessary degree of similarity. Authors differ on what they consider the disturbances of function comprising Parkinsonism (Table II), and they do not always abide by their own criteria of the syndrome. If a comprehensive definition is used (e.g., Critchley, 1929; Denny-Brown, 1959) Parkinsonism can be due to manganese poisoning, yet this resembles Wilson's disease rather than paralysis agitans (Turner, 1955): also Parkinsonism may occur in Huntington's chorea (Bittenbender and Quadfasel, 1962; Denny-Brown, 1962) yet these ordinarily are thought of as contrasting types of extrapyramidal disorder (Jakob, 1925). Critchley's (1929) criteria allowed him to describe an 'arteriosclerotic Parkinsonism' with tremor as an unusual feature, whereas a more restrictive definition would not have permitted the use of 'Parkinsonism' in this connexion.
Perhaps failure to appreciate the differing scope of various definitions of 'Parkinsonism', and desire to have a more tangible aetiology for paralysis agitans than degeneration, led to more being included in the term 'arteriosclerotic Parkinsonism' than was justified. What Critchley (1929) originally described as arteriosclerotic Parkinsonism may still be valid and it may be only the later extension of the concept which should be suspect. The present study has been concerned with cases showing both Parkinsonian rigidity and tremor, and its outcome therefore provides no evidence against Critchley's (1929) view, but only against later and broader concepts of arteriosclerotic Parkinsonism.

Obviously a generally accepted definition of Parkinsonism would be desirable. Perhaps it could be along the lines of Alvord's (1958) 'typical' and 'atypical' Parkinsonism, though preferably on a pathological basis, as Vogt's school attempted in their 'nigral' and 'extranigral' Parkinsonism (Beheim-Schwarzbach, 1952). When it is possible to describe the pathological abnormality responsible for each element of the disturbance of function in such Parkinsonism, the role of arteriosclerosis in producing the disorder can be more validly assessed. Until such data are available it seems prudent to approach critically the subject of arteriosclerotic and other types of symptomatic Parkinsonism.

\section{SUMMARY}

Some of the literature pertaining to arteriosclerotic Parkinsonism has been reviewed.

It appears that both the pathological and clinical bases of the concept are somewhat uncertain, and even the meaning of the word 'Parkinsonism' varies from author to author.

The present study failed to demonstrate any significant excess of clinically detectable arterial disease in patients with Parkinsonian over matched control subjects; this casts further doubt on the role of arteriosclerosis in the production of Parkinsonian rigidity and tremor. 


\section{REFERENCES}

Alexander, L. (1942). Res. Publ. Ass. nerv. ment. Dis., 21, 334. Alners, B. J. (1945). Clinical Neurology, Davis, Philadelphia.

Alvord, E. C. Jr. (1958). In Pathogenesis and Treatment of Parkinsonism, edited by W. S. Fields, pp. 161-186. Thomas, Springfield, Illinois.

Aring, C. D. (1962). Arch. Neurol. (Chic.) 6, 1.

Baker, A. B. (1962). Clinical Neurology, 2nd ed. Hoeber, New York. Beheim-Schwarzbach, D. (1952). J. nerv. ment. Dis., 116, 619.

Bittenbender, J. B. and Quadfasel, F. A. (1962). Arch. Neurol. (Chic.), $7,275$.

Brain, Lord (1962). Diseases of the Nervous System, 6th ed. Oxford University Press, London.

Brissaud, E. (1895). Lecons sur les Maladies nerveuses. Masson, Paris. Buzzard, T. (1882). Brain, 4, 473.

Cecil, R. L. and Loeb, R. F. (1959). A Textbook of Medicine, 10th ed. Saunders, Philadelphia.

Charcot, J. M. (1877). Lectures on Diseases of the Nervous System. New Sydenham Society, London.

Critchley, M. (1929). Brain, 52, 23.

Davison, C. (1942). Res. Publ. Ass. nerv. ment. Dis., 21, 267.

Denny-Brown, D. (1954). In Parkinsonism and its Treatment, edited by L. J. Doshay, pp. 17-33. Lippincott, Philadelphia.

(1959). In A Textbook of Medicine, edited by R. L. Cecil and R. F. Loeb, 10th ed. Philadelphia.

- (1962). The Basal Ganglia. Oxford University Press, London.

Doshay, L. J. (1954). In Parkinsonism and its Treatment, edited by L. J. Doshay, pp. 51-75. Lippincott, Philadelphia. (1960). J. Amer. med. Ass., 174, 1962.

Foerster, O. (1909). Allg. Z. Psychiat., 66, 902.

Foix, C. (1921). Rev. neurol., 28, 593.

- and Nicolesco, J. (1925). Les Noyaux gris centraux et la Région Mésencéphalo-sous-Optique. Masson, Paris.

Garland, H. (1955). Proc. roy. Soc. Med., 48, 867.

Greenfield, J. G. (1955). In James Parkinson (1755-1824), edited by M. Critchley, pp. 219-143. Macmillan, London.

- , and Bosanquet, F. D. (1953). J. Neurol. Neurosurg. Psychiat., 16, 213.

(1958). Neuropathology. Arnold, London.

Grinker, R. R., Bucy, P. C., and Sahs, A. L. (1959). Neurology, 5th ed. Thomas, Springfield, Illinois.

Hall, A. J. (1923), Lancet, 1, 731.

Hassler, R. (1938). J. Psychol. Neurol., 48, 387.

-, Riechert, T., Mundinger, F., Umbach, W., and Ganglberger, J. A. (1960). Brain, 83, 337.

Haymaker, W. (1959). In The Shaking Palsy, A Symposium, edited by H. Elliott, and B. Nashold. McGill University Press, Montreal.
Herz, E., and Meyers, R. (1962). In Clinical Neurology, 2nd ed., edited by A. B. Baker. Hoeber, New York.

Heyman, A. (1959). In The Shaking Palsy, A Symposium, edited by H. Elliott, and B. Nashold. McGill University Press, Montreal. (\$

Hirano, A., Kurland, L. T., Krooth, R. S., and Lessell, S. (1961). Brain, 84, 642.

Howell, D. (1959). In The Shaking Palsy, A Symposium, edited by H. Elliott, and B. Nashold. McGill University, Montreal.

Hunt, J. R. (1917). Brain, 40, 58.

- (1937). In Nelson's New Loose-Leaf Living Medicine. New York.

Jager, W. A. den Hartog, and Bethlem, J. (1960). J. Neurol. Neurosurg Psychiat., 23, 283.

Jakob, A. (1925). Arch. Neurol. Psychiat. (Chic.), 13, 596.

Janischewsky, A. (1909). Rev. neurol., 17, 823.

Keith, N. M., Wagener, H. P., and Barker, N. W. (1939). Amer. J. med. Sci., 197, 332.

Keschner, M., and Sloane, P. (1931). Arch. Neurol. Psychiat. (Chic.), 25, 1011.

Klaue, R. (1940). Arch. Psychiat. Nervenkr., 111, 251.

Lewy, F. H. (1913). Dtsch. Z. Nervenheilk., 50, 50.

Mackintosh, A. W. (1903). Scot. med. surg. J., 13, 325.

Maillard, G. (1907). Thèse de Paris, cited by Greenfield, J. G. (1955), loc. cit.

Merritt, H. H. (1959). Textbook of Neurology, 2nd ed. Lea and Febiger,

Philadelphia.
Parkinson, J. (1817). An Essay on the Shaking Palsy. Reprinted in $\overrightarrow{0}$ (1955). James Parkinson (1755-1824), edited by M. Critchley.Macmillan, London.

Purves-Stewart, J., and Worster-Drought, C. (1952). The Diagnosis of Nervous Diseases, 10th ed. Arnold, London.

Schneider, A., and Williams, J. M. (1949). In Fundamentals of Internal Medicine, 3rd ed., edited by W. M. Yater, ch. 16, pp. 928-1040.7 New York.

Schwab, R. S., and England, A. C. (1958). J. chron. Dis., 8, 488.

Souques, A. (1921). Rev. neurol., 28, 534.

Tretiakoff, C (1919). Thdse de Paris, cited by Foix, C (1921), loc.

Turner, J. W. A. (1955). Lancet, 1, 661.

Walshe, F. M. R. (1955). In James Parkinson (1755-1824), edited $\mathfrak{B y}_{y}$ M. Critchley, pp. 245-268. Macmillan, London.

Walton, J. N. (1961). Essentials of Neurology. Pitman Medical P부lishing Co., London.

Wilson, S. A. Kinnier, (1954-5). Neurology, edited by A. N. Bruce, 2nd ed. Butterworth, London.

Wolf, A. (1954). In Parkinsonism and its Treatment, edited by Ly Doshay, pp. 35-49. Lippincott, Philadelphia.

Yater, W. M. (1949). Fundamentals of Internal Medicine, 3rd क्षे. Appleton-Century-Crofts, New York. 